\title{
TINGKAH LAKU BERTELUR BURUNG MALEO (Macrocephalon maleo) DI MUARA PUSIAN KAWASAN TAMAN NASIONAL BOGANI NANI WARTABONE KECAMATAN DUMOGA TIMUR KABUPATEN BOLAANG MONGONDOW
}

\author{
Zibran Poli *, Bobby Polii ${ }^{\text {** }}$ dan Umar Paputungan *** \\ * Program Pascasarjana, Universitas Sam Ratulangi, Manado. \\ ** Fakultas Pertanian, Universitas Sam Ratulangi, Manado. \\ *** Fakultas Peternakan, Universitas Sam Ratulangi, Manado.
}

\begin{abstract}
ABSTRAK
Taman Nasional Bogani Nani Wartabone merupakan kawasan benteng pertahanan dari berbagai spesies flora dan fauna untuk tetap bertahan hidup, diantaranya burung maleo (Macrocephalon maleo) yang merupa-kan burung endemik Sulawesi. Tujuan peneli-tian ini adalah untuk mengetahui dan mempe-lajari tingkah laku bertelur Burung Maleo, kedalaman dan suhu lubang peneluran, jumlah kunjungan burung maleo dan ancaman ditem-pat peneluran maleo. Penelitian dilaku-kan dengan metode pengamatan langsung di lokasi peneluran maleo. Data yang diperoleh di lokasi penelitian diolah secara deskriptif yaitu menggambarkan fakta dan fenomena yang ada di lapangan dan disajikan melalui pembahasan objektif dari hasil tabulasi data pengamatan lapangan. Hasil pengamatan menunjukkan aktifitas saat bertelur meliputi penggalian lubang peneluran, peletakkan telur, penim-bunan lubang, pembuatan lubang tipuan, sedangkan aktifitas sesudah bertelur meliputi istirahat, mencari makan dan kembali kehutan. Rata-rata lama waktu peneluran memakan waktu 1-3 jam, mulai dari mencari tempat, menggali lubang secara bergantian, bermain, sampai bertelur. Kedalaman lubang peneluran rata-rata $41,8 \pm 14,28 \mathrm{~cm}$ dan suhu lubang peneluran rata-rata $29-35^{\circ} \mathrm{C}$, suhu udara peneluran rata-rata $27^{\circ} \mathrm{C}-34^{0} \mathrm{C}$. Burung maleo lebih banyak bertelur di sekitar menara I dibandingkan di menara II, karena di sekitar menara I masih terdapat pohon-pohon yang dapat dijadikan naungan sekaligus tempat berlindung dari predator dan lebih bersih untuk mempermudah penggaliannya, diban-dingkan di menara II yang
\end{abstract}

***Korespondensi (corresponding author):

Email: umar_fapet@yahoo.com hanya ditumbuhi kano-kano (Saccharum spontaneum) dan alang-alang (Imperata cylindrical), sehingga keamanannya tidak terjamin serta memper-sulit penggalian lubang peneluran. Dijumpai dan dihitung secara langsung jumlah burung maleo berkunjung di tempat peneluran se-banyak 28 pasang dan 1 jantan tanpa pasangan yang terlihat, serta 9 pasang yang terdengar, sehingga total burung maleo 37 pasang terbagi dari 37 ekor betina dan 38 ekor jantan. Jumlah telur yang ditemukan selama penelitian ber-jumlah 42 butir, yang rusak 2 butir, menetas (chicks, anak burung) berjumlah 40 ekor melalui tempat penetasan buatan (Artificial Hatchery) di lokasi penelitian.

Kata Kunci: Tingkah laku bertelur, burung maleo (Macrocephalon maleo).

\section{ABSTRACT}

EGG LAYING BEHAVIOR OF MALEO BIRD (Macrocephalon maleo) AT MUARA PUSIAN NATURAL CONSER-VATION IN BOGANI NANI WARTA-BONE NATIONAL PARK, EAST DUMO-GA DISTRICT OF BOLAANG MONGON-DOW REGENCY

Bogani Nani Wartabone National Park was conservation living area of the all flora and fauna species including maleo bird (Macrocephalon maleo) as the endemic bird in Sulawesi Island. Objective of this research was to study behavioral laying egg of maleo bird, temperature and hole deep of laying egg, total visitation of maleo bird at laying egg hole places and predator threat around laying egg hole places. Research was conducted by direct observation at the maleo habitat of laying egg holes place. Data obtained were analyzed descriptively to describe the facts and phenomena occurring at the bird habitat. Results showed that bird activities before laying 
egg at holes included digging the laying egg hole, laying egg in the hole, heaping up egg hole, digging false egg holes. Bird activities after laying egg at holes included pause and look for feed around holes and then they flied to the forest area. The average times of laying egg were 1 to 3 hours, started from looking for area of hole, digging holes, playing around egg holes area to the end of laying egg in the hole. The averages of egg holes deep were $41.8 \pm 14.28 \mathrm{~cm}$ and egg holes temperatures were $27^{\circ} \mathrm{C}-34^{0} \mathrm{C}$. Maleo birds were laying their eggs more around Tower I compared with around Tower II. Around Tower I had dense vegetation of trees used as shelter, protection place from predators, clean area from scrubs for easy digging holes of laying egg. Around Tower II, there were growing scrubs (Saccharum spontaneum) and coarse grass (Imperata cylindrical) causing unsecure and difficult digging holes by maleo birds in laying their eggs. The total visitations of maleo birds around egg holes areas were visibly observed of 28 pairs and 1 male without spouse and 9 pairs found by auditory observation. Therefore, there were 37 pairs consisted of 37 females and 38 males of maleo birds observed. The total eggs obtained during observation were 42 eggs, consisted of 2 damaged eggs and 40 hatching eggs using the artificial hatchery at study location.

Key words: Behavioral laying egg, maleo bird (Macrocephalon maleo).

\section{PENDAHULUAN}

Sebagai bagian dari wilayah Wallacea, kawasan Taman Nasional Bogani Nani Wartabone (TNBNW) merupakan salah satu kawasan yang mempunyai ekosistem asli dan banyak mengandung keanekaragaman potensi jenis sumber daya alam yang khas dan unik yang perlu dikembangkan (Baker, 2002; van As, 2007). Kawasan TNBNW ini adalah benteng pertahanan dari berbagai spesies flora dan fauna untuk tetap bertahan hidup, diantaranya burung maleo (Macrocephalon maleo) yang merupakan burung endemik Sulawesi (Gunawan, 1995). Di TNBNW sendiri, habitat burung maleo terdapat 7 lokasi, yaitu Tambun, Matayangan, Muara Pusian (Gambar 1), Hungayono, Pohulongo, Leda-leda, dan Pinomongua (Gorog, et al. 2005).

Badan konservasi dunia, yaitu IUCN (International Union for Conservation of Nature Resources) telah mencantumkan jenis maleo sebagai satwa liar yang terancam punah dengan kategori "Rawan" sejak tahun 1966. Pemerintah Indonesia menetapkan Burung Maleo sebagai satwa yang dilindungi berdasarkan Surat Keputusan Menteri Pertanian Nomor: 421/KPTS/UM/8/1970 tanggal 26 Agustus 1970. Pemerintah Tingkat I Sulawesi Utara melalui Surat Keputusan No. 522/XI/2787 tanggal 21 Juli 1987 telah melarang penangkapan burung maleo dan pengambilan telur maleo. Dalam rangka meningkatkan pengetahuan dan mengungkap-kan secara mendalam cara pelestarian jenis burung maleo melalui proses regenerasi maka perlu menelaah behavior burung maleo.

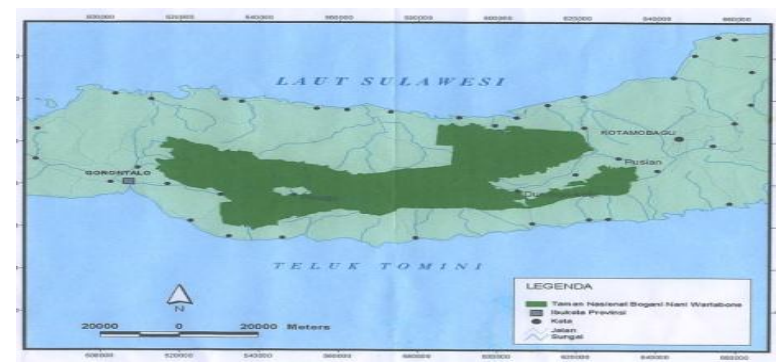




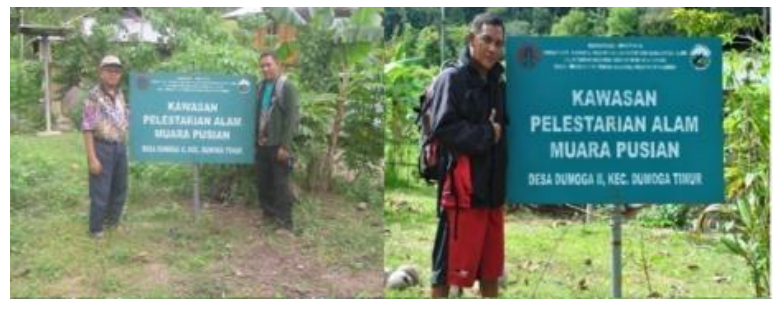

Gambar 1. Peta Kawasan Pelestarian Alam Di TNBNW Wilayah Muara Pusian Desa Dumoga II, Kecamatan Dumoga Timur.

Salah satu cara adalah melakukan penelititan terhadap "Tingkah Laku Bertelur Burung Maleo di Muara Pusian Dalam Kawasan Taman Nasional Bogani Nani Wartabone (TNBNW) Kecamatan Dumoga Timur Kabupaten Bolaang Mongondow". Tujuan penelitian ini adalah a) untuk mengetahui dan mempelajari tingkah laku Burung Maleo sebelum bertelur dan sesudah bertelur; b) untuk mengetahui kedalaman lubang peneluran dan suhu lubang Peneluran; c) jumlah kunjungan burung maleo di tempat peneluran; dan d) ancaman ditempat peneluran maleo.

\section{METODOLOGI PENELITIAN}

\section{A. Tempat dan Waktu Penelitian}

Penelitian ini dilaksanakan pada Kawasan Taman Nasional Bogani Nani Wartabone di Muara Pusian Kecamatan Dumoga Timur Kabupaten Bolaang Mongondow (Gambar 1). Lama penelitian terhitung mulai pada bulan Maret 2015 sampai dengan bulan Mei 2015.

\section{B. Materi dan Alat Penelitian}

Alat dan bahan yang digunakan dalam penelitian ini, yaitu Binoculler, Jam Tangan
Digital, ATM (Alat Tulis Menulis), Kamera Foto, Peta Kawasan Taman Nasional Bogani Nani Wartabone, Thermometer Tanah, Tower Intai, Pesola scales, Soil tester $(\mathrm{pH}$ meter), Data Sheet.

\section{Pengambilan Data}

Data yang dikumpulkan terdiri dari data primer dan sekunder. Metode dalam penelitian ini adalah melakukan pengamatan langsung, dengan menggunakan Binoculler dan melakukan pengamatan di menara yang ada di Muara Pusian (Gambar 2).

Pengamatan tingkah laku Maleo dalam penelitian dilakukan, yaitu (1) Penetapan jam pada saat maleo datang ketempat peneluran dan pada saat maleo meninggalkan tempat peneluran, (2) Tingkah Laku Sebelum Bertelur, (3) Tingkah Laku Saat Bertelur dan (4) Tingkah Laku Sesudah Bertelur.

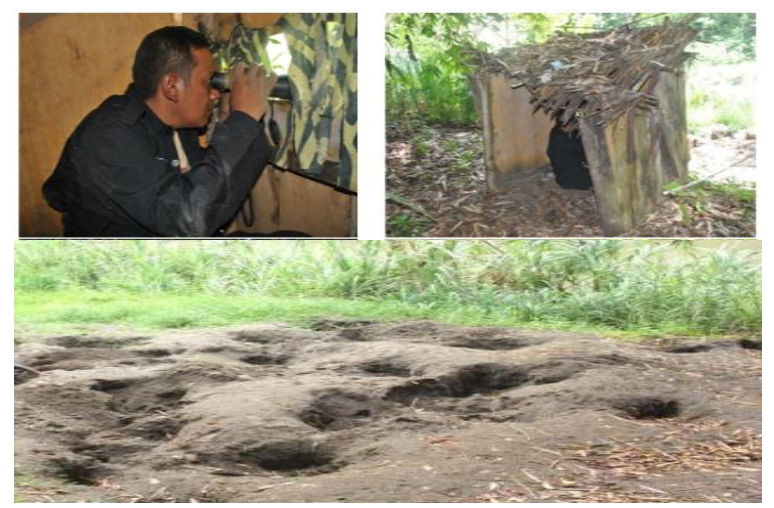

Gambar 2. Pengamatan Proses Maleo Bertelur Di Lokasi Peneluran Muara Pusian, TNBNW.

\section{Variable Pengamatan}

Variabel yang diamati dalam penelitian ini adalah (1) Lama waktu peneluran, (2) Frekwensi kunjungan pada 
tempat peneluran (di tower mana maleo sering datang/aktif) kedalaman dan suhu tempat bertelur, (3) Jumlah burung dan jenis kelamin yang ada ditempat peneluran serta jumlah telur, (4) Ancaman dan penyebab penurunan jumlah populasi, dan (5) Habitat tempat bertelur.

\section{E. Prosedur Kerja}

Prosedur kerja meliputi

Pembersihan Lokasi Penelitian, (2) Monitor tingkah laku bertelur burung maleo lewat menara intai (tower) (Gambar 2), (3) Monitor/mencari telur sesudah peneluran (Gambar3), (4) Monitor ancaman terhadap populasi burung maleo, (5) Mencatat variabel di lokasi penelitian, dan (6) Perhitungan dan analisa data pada akhir pengamatan di lapangan (Paputungan, 2006; Paputungan, 2007).

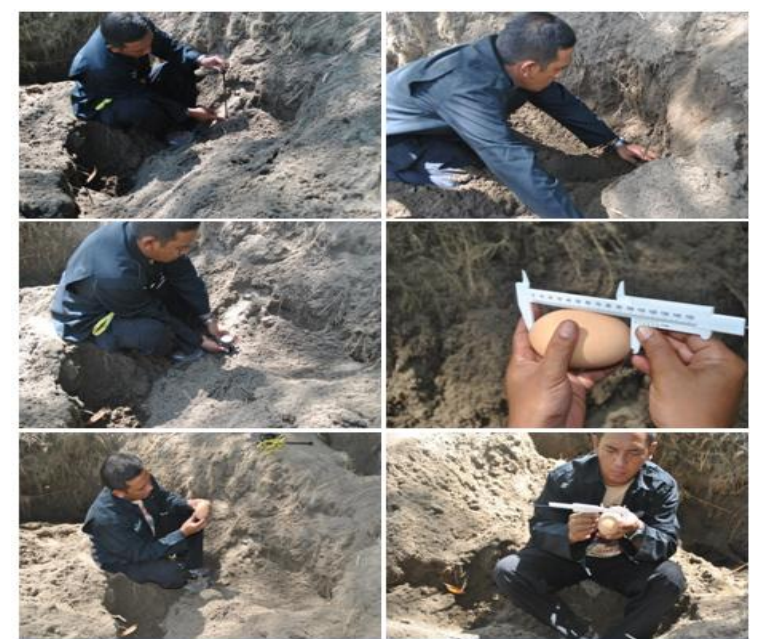

Gambar 3. Pengukuran kedalaman, suhu lubang, jumlah dan ukuran telur maleo.

\section{F. Analisis Data}

Data yang diperoleh diolah secara deskriptif yaitu menggambarkan fakta dan fenomena yang ada di lapangan dan disajikan melalui pembahasan objektif dari hasil tabulasi data pengamatan lapangan.

\section{HASIL DAN PEMBAHASAN}

\section{A. Tingkah Laku Burung Maleo Sebelum Bertelur}

Sebelum maleo turun ke dasar hutan untuk menyiapkan sarang, sepasang induk maleo biasanya mempelajari atau mengamati situasi keamanan lapangan dari atas pohon didekat lapangan sarang. Pada pohon tersebut mereka juga melakukan aktifitas bermain (loncat-loncat) diatas pohon, jumlah maleo antara 2-8 ekor. Burung maleo tidak bisa terbang terlalu tinggi, namun hanya terbang dari pohon/dahan satu kepohon/dahan lainnya. Maleo bertengger pada cabang-cabang pohon dengan ketinggian antara 15-20 meter dari tanah/lantai hutan.

Aktifitas sebelum bertelur di lantai hutan dapat berlangsung antara 1-3 jam dan hal ini sangat tergantung dengan kondisi atau situasi keberadaan pakan di lapangan persarangan. Burung maleo cenderung menggunakan sarang yang sama atau sarang yang pernah digunakan sebelumnya. Sarang ini mungkin diklaim sebagai miliknya (Gorog, et al. 2005)). Dari penjelasan dan uraian di atas, dapat diduga bahwa tingkah laku sebelum bertelur terutama ditujukan untuk menentukan tempat sarang lubang 
yang cocok dan terbaik (suitable) untuk meletakkan/ membenamkan telur.

\section{B. Tingkah Laku Maleo Saat Bertelur}

Pada saat akan bertelur maleo mencari tempat bertelurnya sendiri. Pemilihan lokasi peneluran dilakukan oleh betina, sedangkan yang jantan hanya mengikuti saja dari belakang. Burung maleo ini terlihat melakukan pembagian tugas/pekerjaan, dimana bila burung jantan menggali lubang, maka burung betina akan bertugas sebagai keamanan, yaitu bertugas untuk mengawasi dan menjadi pengintai dengan cara berdiri pada tempat yang agak tinggi di dekat tempat penggalian dan begitu pula sebaliknya. Apabila situasi tidak aman (terganggu) si pengintai memberitahu pada penggali lubang dan keduanya akan terbang meninggalkan tempat peneluran, dan apabila situasi/keadaan sudah aman, baru burung maleo akan kembali melanjutkan penggalian lubang untuk selanjutnya bertelur.

Burung maleo akan menyelesaikan tugasnya dari menggali lubang secara bergantian sampai bertelur memakan waktu antara 30-40 menit. Burung maleo akan menyelesaikan tugasnya menggali lubang secara bergantian memakan waktu selama 34 jam (Tarmuji, 1978). Hal ini diduga tergantung pada tekstur dan temperatur tanah serta intensitas gangguan. Burung maleo tidak melakukan dan tidak meletakkan telurnya sedalam mungkin yang bisa dilakukannya, tetapi telur diletakkan pada kedalaman yang memiliki temperature yang dianggap cocok untuk penetasan (Mac Kinnon, 1987).

Setelah melakukan penggalian lubang, maleo betina akan masuk kedalam lubang untuk bertelur, dan maleo jantan berada diatas tepat pinggir lubang sambil melakukan pengawasan. Maleo betina berada didalam lubang untuk bertelur memakan waktu antara 2-5 menit. Setelah maleo betina bertelur atau keluar dari lubang, maka sepasang maleo melakukan penimbunan terhadap lubang tersebut dengan tanah/pasir galian. Burung maleo dalam melakukan penimbunan benar-benar sangat jeli dan cermat, dimana lubang bekas timbunan tersebut benar-benar seperti tidak ada bekas galian. Salah satu keunikan dari burung ini adalah selain membuat sarang/ lubang untuk bertelur, sepasang burung maleo akan menggali lubang lain disekitar tempat mereka meletakkan telurnya yang diduga difungsikan sebagai penyamaran terhadap predator.

Referensi yang mengatakan bahwa induk betina pingsan setelah bertelur tidak pernah terbukti, tetapi setelah bertelur maleo betina seperti menari-nari diatas lubang penelurannya agar lubang tersebut benar benar padat akibat injakan. Diduga burung maleo bertelur setiap 12-13 hari sekali atau 30 telur pertahun (Mac Kinnon, 1987). 
Menurut Gorog, et al. (2005), produksi telur maleo berkisar antara 8-12 butir pertahun. Butchart and Baker (2000) memper-kirakan jumlah telur per induk berkisar antara 16-18 butir berdasarkan pemeriksaan ovary.

\section{Tingkah Laku Maleo Sesudah Bertelur}

Setelah bertelur dan melakukan penimbunan, sepasang maleo tidak langsung terbang atau kadang-kadang pasangan maleo langsung terbang ke pohon terdekat untuk beristirahat. Kadang-kadang pula sepasang maleo ini berjalan-jalan di atas tanah sambil mengais dan mematuk-matuk tanah untuk mencari makanan dan air serta apabila ada gangguan baru mereka terbang kembali ke hutan (Gambar 4).

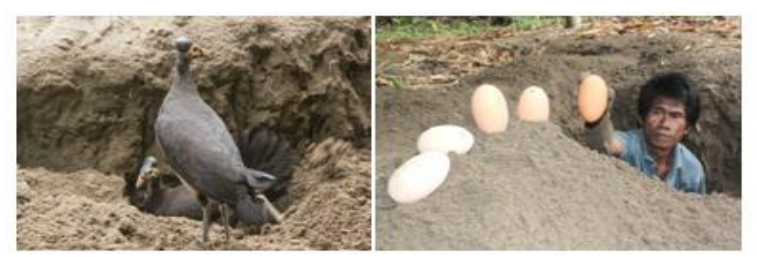

Gambar 4. Maleo selesai bertelur dan petugas konservasi maleo (Tomo Lomamay) memindahkan telur dari lubang peneluran ke penetasan buatan (Artificial Hatchery).

Ada juga burung maleo sehabis bertelur atau menimbun telurnya langsung terbang ke atas pohon/dahan. Maleo tidak pernah mengawasi atau mengusik telur yang telah dipendamnya di dalam tanah sampai akhirnya menetas. Maleo hanya menyiapkan lubang pengeraman di tempat yang dianggapnya paling aman dari berbagai gangguan dan menerima panas dengan baik (Gunawan 1995).
Burung maleo merupakan burung yang sangat sensitive dan takut terhadap manusia (Homo sapiens), elang (Spilornis rufipectus) dan elang (Spizaetus lanceotalus), Biawak (Varanus salvator), ular tanah (Calloselasma rhodostoma) dan lain-lain. Reaksi burung maleo terhadap kehadiran manusia, elang, biawak dan predator lain adalah terbang menjauh pada jarak sekitar 20 meter dimana burung maleo berada diatas cabang/dahan pohon yang tingginya \pm 5-12 meter.

Burung maleo juga peka terhadap bunyi, bayangan atau suara yang asing baginya. Pada waktu menggali lubang untuk bertelur, suara ranting atau serasah yang terinjak atau suara "klik" kamera pada jarak 5-10 meter dapat membuat burung maleo terbang ke cabang pohon terdekat, dan apabila keadaan sudah aman baru burung maleo turun lagi melanjutkan aktifitasnya.

\section{Lama Waktu Peneluran, Kedalaman dan Suhu Tempat Bertelur}

\section{Lama Waktu Peneluran}

Aktifitas sebelum bertelur (dilantai hutan) dapat berlangsung antara 30-90 menit, dan ini sangat tergantung dengan kondisi atau situasi keberadaan tempat peneluran, apakah ada ancaman atau tidak. Selama penelitian rata-rata lama waktu peneluran burung maleo memakan waktu 13 jam. Mulai dari mencari tempat, menggali lubang, bermain, sampai bertelur. Waktu 
akan lebih lama lagi jika terdapat gangguan dari predator lain. Maleo betina bertelur didalam lubang rata-rata memakan waktu 510 menit.

\section{Kedalaman dan Suhu Tempat Bertelur}

Burung maleo melakukan dan tidak meletakkan telurnya sedalam mungkin, tetapi telur diletakkan pada kedalaman yang memiliki temperatur yang dianggap cocok untuk penetasan. Dari hasil penelitian, kedalaman lubang rata-rata $38-96 \mathrm{~cm}$, suhu lubang peneluran (Egg Pit) rata-rata $29^{\circ} \mathrm{C}$ $35^{\circ} \mathrm{C}$, suhu udara peneluran rata-rata $27^{\circ} \mathrm{C}$ $34^{0} \mathrm{C}$.

\section{E. Musim Bertelur, Habitat Maleo dan Frekuensi Kunjungan Pada Tempat Peneluran (di Tower manara maleo sering datang/aktif)}

Musim bertelur dan habitat dengan sumber panas geothermal tampaknya berlangsung sepanjang tahun dengan puncaknya pada beberapa bulan tertentu. Menurut informasi pengumpul telur, musim bertelur burung maleo di lokasi peneluran Muara Pusian berlangsung dari bulan Agustus sampai Oktober. Menurut Dekker and McGowan (1995) musim bertelur burung maleo di habitat bersumber panas geothermal di Sulawesi Utara mencapai puncaknya pada bulan Oktober sampai bulai Mei dan Juni. Musim bertelur di habitat bersumber panas matahari (dipantai) umumnya berlangsung selama musim kemarau. Dipantai Selatan Sulawesi Utara berlangsung antara bulan September sampai Maret, tetapi dipantai utara berlangsung antara bulan Maret sampai September. Menurut Gorog, et al. (2005) telur dihasilkan setiap bulan sepanjang tahun. Di Morowali (Sulawesi Tengah) musim bertelur di habitat bersumber panas matahari langsung pada bulan September sampai Maret (Butchart and Baker, 2000). Di Sulawesi Tenggara musim bertelur berlang-sung pada bulan Mei-Juni dan November-Januari (Summers, 2007).

Musim bertelur maleo di pedalaman adalah pada bulan Oktober - April, sedangkan di pantai berlangsung antara Juni - September. Diduga pada musim tersebut merupakan kondisi terbaik untuk bertelur karena hujan tidak banyak turun dan sinar matahari di pantai cukup terik sehingga memberikan kondisi pengeraman yang optimal (Argeloo and Boromo, 1991).

Areal peneluran maleo di Muara Pusian tersebut terdapat sumber air panas, pada umumnya lubang-lubang peneluran maleo yang berada di dekat sumber air panas tidak terlalu dalam berkisar antar 15-40 cm. sedangkan yang agak jauh dari sumber air panas mempunyai kedalaman berkisar antara 40-90 cm (Gambar 5).

Diduga hal ini dikarenakan faktor suhu dan kelembaban tanah. Hasil 
pengamatan di dua menara, yaitu menara I (Itundud) dan menara II (Ilangsikan) bahwa ternyata burung maleo lebih banyak bertelur disekitar menara I dibandingkan dengan menara II. Hal ini disebabkan karena disekitar menara I masih terdapat pohonpohon yang dapat dijadikan naungan sekaligus tempat berlindung dari para predator dan lebih bersih sehingga mempermudah penggaliannya, dibandingkan di menara II yang hanya ditumbuhi oleh kano-kano (Saccharum spontaneum) dan alang-alang (Imperata cylindrical), sehingga keamanannya tidak terjamin serta mempersulit penggalian lubang peneluran.

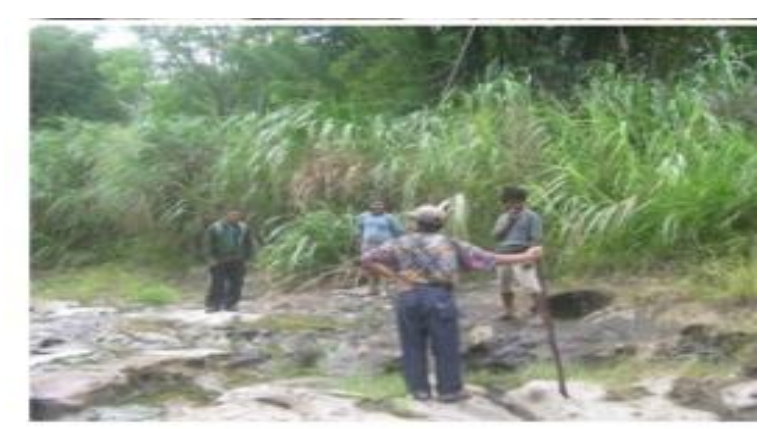

Gambar 5. Sumber Air Panas Di Pinggiran Sungai Ongkag Lokasi Peneluran Maleo (Penelitian).

\section{F. Jumlah Burung, Jenis Kelamin di Lokasi Penelitian dan Jumlah Telur}

Perjumpaan burung maleo di lokasi peneluran menggunakan metode pengamatan secara langsung. Pengamatan dilakukan pada saat maleo keluar dari hutan, berada diatas pohon, sampai dengan burung maleo turun ke tanah untuk bertelur maupun bermain, serta mencari makan, hingga setelah bertelur. Pengamatan/pengintaian dilakukan dalam menara intai (Tower) yang ditempatkan dilokasi yang strategis yaitu kurang lebih berada ditengah-tangah areal di mana konsentrasi burung maleo untuk bertelur.

Pengamatan dilakukan pada pagi hari yaitu jam $06 .{ }^{00}-10 .^{00}$ Wita. Dalam 3 bulan penelitian ditemukan atau di jumpai dan dihitung secara langsung jumlah burung maleo secara keseluruhan berjumlah 45 pasang yang terlihat, 9 pasang yang terdengan, 10 pasang yang bertengkar dan 1 jantan tanpa pasangan. Berarti keseluruhannya yang terlihat 91 ekor terbagi dari 45 ekor betina dan 46 ekor jantan.

Dalam penelitian ini, tidak diperhatikan serta dianalisa burung yang datang hari ini, juga burung yang telah datang kemarin, sehingga jumlah burung maleo yang tertera dalam Table 1, bukan keadaan populasi maleo sekarang ini. Hal ini disebabkan tujuan utama dari penelitian ini adalah menganalisa dan mengetahui tingkah laku burung maleo khususnya tingkah laku bertelur. Jumlah telur yang ditemukan selama penelitian berjumlah 42 butir, yang rusak 2 butir, menetas (chicks, anak burung) berjumlah 40 butir.

\section{G. Ancaman/Penyebab Jumlah Populasi dan Upaya penanggulangan}

Dalam tahun-tahun belakangan ini populasi satwa di Sulawesi Utara telah mengalami tingkat penurunan yang sangat 
parah. Populasi maleo juga mengalami penurunan dan terpisah-pisah mengakibatkan spesies ini semakin mendekati kepunahan (van As, 2007). Pengambilan telur, perusakan habitat, dan perburuan burung merupakan ancaman terbesar, dengan pembukaan hutan secara masal di Matayangan, serta kebakaran hutan dan pembukaan areal perkebunan oleh masyarakat Serta Ilegal loging juga merupakan masalah di Muara Pusian. Selama 10-15 tahun terakhir ini populasi maleo di muara pusian menurun tajam dari 150-200 pasang sampai tinggal 50-70 pasang, suatu penurunan sebesar 47-65\% (Manik, 2008; Lee dkk. 2001). Hal ini diperkirakan oleh tingginya tekanan manusia terhadap burung ditempat tersebut, terutama tekanan perburuan langsung melalui penembakan burung.

Pengambilan yang berlebihan dan predator dari spesies domestik merupakan masalah yang berarti (van As, 2007). Penelitian telah mengidentifikasikan variabel fisik dalam penggalian (Gunawan, 1994; Lee dkk 2001) dan predator-predator alam (Mac Kinnon, 1987; Gorog, et al. 2005) sebagai faktor yang menentukan kemungkinan kematian anak burung maleo dan jenis Megapoda lainnya. Ancaman yang ditemukan selama penelitian yaitu adanya Pemburu yang lewat, burung elang (spilornis rufipectus), biawak, ular, anjing. Populasi burung Maleo di Muara Pusian diperkirakan hanya kecil sekitar \pm 20 -40 pasang (Manik, 2008). Hal ini disebabkan oleh kombinasi ancaman alami, banjir dan predator, baik predator alami seperti biawak, Ular dan elang serta terutama oleh manusia sendiri (Sulu, 1991; van As, 2007).

Dengan adanya ancaman predator burung maleo yang datang ke nesting ground, langsung meninggalkan lubang peneluran. Upaya penanggulangan proses penu-runan populasi burung maleo di muara Pusian akibat predator adalah membangun tempat penetasan buatan (Artificial Hatchery) di lokasi peneluran burung maleo (Gambar 6).

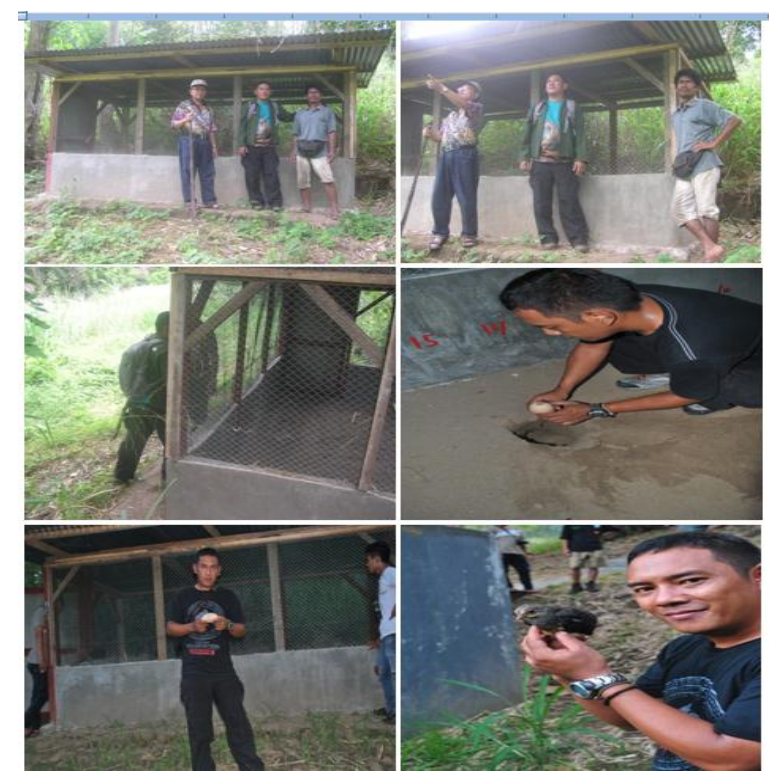

Gambar 6. Tempat Penetasan Buatan (Artificial Hatchery) Burung Maleo di Habitat Maleo Muara Pusian TNBNW.

Telur maleo yang baru di letakkan induk dalam lubang yang terlihat melalui pemantauan segera digali kembali dan dibenamkan dalam lubang tempat penetasan 
buatan dengan memberikan tanda berupa tanggal benam dan nomor lubang. Anak dari telur maleo yang telah menetas (Gambar 8) akan dipindahkan ke tempat penangkaran anak burung maleo sebelum dilepas, yang terbuat dari terali kawat dengan ukuran rongga sekitar $3 \mathrm{~cm}$. Hal ini dimaksudkan untuk mencegah terjadinya pemangsaan predator pada anak maleo yang belum kuat untuk terbang agak jauh (Tasirin, 2007).

Table 1. Pasangan Burung Maleo berkunjung di tempat peneluran (Nesting Ground) Kawasan Pelestarian Alam Muara Pusian Selama Pengamatan.

\begin{tabular}{|c|c|c|c|c|c|c|c|}
\hline No & Tanggal Pengamatan & $\begin{array}{c}\text { Jam observasi } \\
\text { awal }\end{array}$ & $\begin{array}{c}\text { Jam } \\
\text { observasi } \\
\text { selesai }\end{array}$ & Terlihat & $\begin{array}{l}\text { Terde- } \\
\text { ngar }\end{array}$ & $\begin{array}{c}\begin{array}{c}\text { Kedalaman } \\
\text { telur di lubang } \\
(\mathrm{cm})\end{array} \\
\end{array}$ & pH \\
\hline 1 & Senin, 02-03-2015 & 06.00 & 10.00 & 1 Pasang & - & 40 & 7,0 \\
\hline 2 & Selasa, 03-03-2015 & 06.00 & 10.00 & - & 1 pasang & - & - \\
\hline 3 & Rabu, 04-03-2015 & 06.00 & 10.00 & 2 Pasang & - & $\begin{array}{l}35 \\
39 \\
\end{array}$ & $\begin{array}{l}\mathbf{7 , 0} \\
\mathbf{7 , 0} \\
\end{array}$ \\
\hline 4 & Kamis, 05-03-2015 & 06.00 & 10.00 & 1 Pasang & 1 pasang & 22 & 7,0 \\
\hline 5 & Jumat, 06-03-2015 & 06.00 & 10.00 & 1 Pasang & - & 49 & 7,0 \\
\hline 6 & Sabtu, 07-03-2015 & 06.00 & 10.00 & 1 Pasang & - & 32 & 7,0 \\
\hline 7 & Minggu, 08-03-2015 & 06.00 & 10.00 & - & - & - & - \\
\hline 8 & Senin, 09-03-2015 & 06.00 & 10.00 & 1 pasang & - & - & - \\
\hline 9 & Selasa, 10-03-2015 & 06.00 & 10.00 & 2 Pasang & - & $\begin{array}{l}41 \\
35\end{array}$ & 7,0 \\
\hline 10 & Rabu, 11-03-2015 & 06.00 & 10.00 & 1 Pasang & - & 48 & 7,0 \\
\hline 11 & Kamis, 12-03-2015 & 06.00 & 10.00 & 2 Pasang & - & $\begin{array}{l}63 \\
67 \\
\end{array}$ & 7,0 \\
\hline 12 & Rabu, 01-04-2015 & 06.00 & 10.00 & - & 2 pasang & - & - \\
\hline 13 & Kamis, 02-04-2015 & 06.00 & 10.00 & - & - & - & - \\
\hline 14 & Jumat, 03-04-2015 & 06.00 & 10.00 & 2 Pasang & 2 pasang & $\begin{array}{l}66 \\
23 \\
\end{array}$ & 7,0 \\
\hline 15 & Sabtu, 04-04-2015 & 06.00 & 10.00 & 4 pasang & - & - & - \\
\hline 16 & Minggu, 05-04-2015 & 0600 & 10.00 & 2 Pasang & - & - & - \\
\hline 17 & Senin, 06-04-2015 & 06.00 & 10.00 & 2 Pasang & - & - & - \\
\hline 18 & Selasa, 07-04-2015 & 06.00 & 10.00 & 1 jantan & - & - & - \\
\hline 19 & Rabu, 08-04-2015 & 06.00 & 10.00 & - & - & - & - \\
\hline 20 & Kamis, 09-04-2015 & 06.00 & 10.00 & 1 Pasang & - & - & - \\
\hline 21 & Jumat, 10-04-2015 & 06.00 & 10.00 & 1 Pasang & - & - & - \\
\hline 22 & Jumat, 01-05-2015 & 06.00 & 10.00 & - & - & - & - \\
\hline 23 & Sabtu, 02-05-2015 & 06.00 & 10.00 & - & - & - & - \\
\hline 24 & Minggu, 03-05-2015 & 06.00 & 10.00 & 1 Pasang & - & - & - \\
\hline 25 & Senin, 04-05-2015 & 06.00 & 10.00 & 1 pasang & 1 pasang & - & - \\
\hline 26 & Selasa, 05-05-2015 & 06.00 & 10.00 & - & - & - & - \\
\hline 27 & Rabu, 06-05-2015 & 06.00 & 10.00 & 1 pasang & - & 36 & 70 \\
\hline 28 & Kamis, 07-05-2015 & 06.00 & 10.00 & - & 1 pasang & - & - \\
\hline 29 & Jumat , 08-05-2015 & 06.00 & 10.00 & - & 1 pasang & - & - \\
\hline 30 & Sabtu, 09-05-2015 & 06.00 & 10.00 & 1 pasang & - & 31 & 70 \\
\hline 31 & Mingu, 10-05-2015 & 06.00 & 10.00 & - & - & - & - \\
\hline & \multicolumn{3}{|c|}{ Sub Total } & 28 Pasang & 9 Pasang & 627 & \\
\hline & \multicolumn{3}{|c|}{ Rata-rata } & \multicolumn{2}{|c|}{ 1,2 pasang/hari } & $41,8 \pm 14,28$ & $\mathbf{7 , 0}$ \\
\hline
\end{tabular}


Anak maleo dibiarkan dalam tempat penangkaran sekitar 3 sampai 4 hari untuk kemudian dilepas (Gambar 7). Tempat penangkaran harus dibuat rapat dan terhindar dari celah ukuran besar, karena anak burung maleo sangat cekatan mencari celah untuk berusaha keluar dan terbang keluar dari tempat penangkaran.

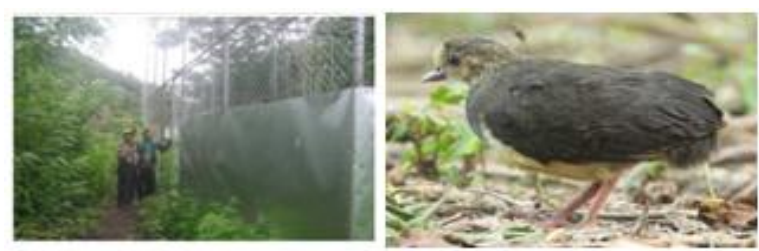

Gambar 7. Tempat Penangkaran Anak Burung Maleo Sebelum Dilepas Di Habitat Hutan Muara Pusiaan TNBNW.

\section{KESIMPULAN DAN SARAN}

\section{A. Kesimpulan}

Dari uraian hasil dan pembahasan dapat ditarik kesimpulan:

1. Tingkah laku bertelur burung maleo sebelum bertelur (anatara pukul $06 .^{00}$ 07. ${ }^{00}$ pagi) meliputi aktifitas saat bertelur meliputi penggalian lubang peneluran, peletakkan telur, penimbunan lubang, pembuatan lubang tipuan. Aktifitas sesudah bertelur meliputi istirahat, mencari makan dan kembali kehutan.

2. Rata-rata lama waktu peneluran memakan waktu 1-3 jam, mulai dari mencari tempat, menggali lubang secara bergantian, bermain, sampai bertelur. Waktu akan lebih lama lagi bila terdapat gangguan. Maleo betina bertelur di dalam lubang rata-rata memakan waktu 2-5 menit.

3. Kedalaman lubang peneluran rata-rata $41.8 \pm 14,28 \mathrm{~cm}$ dan suhu lubang peneluran rata-rata $29-35^{\circ} \mathrm{C}$, suhu udara peneluran rata-rata $27^{0} \mathrm{C}-34^{0} \mathrm{C}$.

4. Selama 1 bulan penelitian dapat dijumpai dan dihitung secara langsung jumlah burung maleo berjumlah 28 pasang yang terlihat, 9 pasang yang terdengar, dan 1 jantan tanpa pasangan, sehingga total burung maleo berkunjung di tempat peneluran 37 pasang terbagi dari 37 ekor betina dan 38 ekor jantan.

5. Jumlah telur yang ditemukan selama penelitian berjumlah 42 butir, yang rusak 2 butir, menetas (chicks, anak burung) berjumlah 40 ekor melalui tempat penetasan buatan (Artificial Hatchery).

\section{B. Saran}

1. Sebaiknya sarang tempat peneluran burung maleo harus selalu dibersihkan dan pohon-pohon yang menjadi naungan dipelihara, karena burung maleo lebih suka bertelur ditempat yang bersih dan mempunyai naungan.

2. Pengelolaan yang berkesinambungan (Sustainable management) untuk tujuan pengamatan dan perlindungan burung maleo harus terus digalakkan melalui penetasan buatan di alam habitat agar populasinya dapat segera pulih. 


\section{DAFTAR PUSTAKA}

Argeloo, and M. Boromo 1991. The Maleo Conservation Project. Preliminary Report. Unpublished.

Baker, G. C. 2002. Conservation status of Maleo Macrocephalon maleo nesting grounds: an update. Megapode Newsletter 16: 4-6.

Butchart, S. H. M.; Baker, G. C. 2000. Priority sites for conservation of maleos Macrocephalon maleo in central Sulawesi. Biological Conservation 94: 79-91.

Dekker, R. W. R. J. and P. J. K.. McGowan. 1995. Megapodes: an Action Plan For Their Conservation 1995-1999. IUCN and World Pheasant Associantion.

Gorog, A.J.; Pamungkas, B.; Lee, R.J. 2005. Nesting ground abandonment by the Maleo (Macrocephalon maleo) in North Sulawesi: identifying conservation priorities for Indonesia's endemic megapode. Biological Conservation 126: 548-555.

Gunawan, H. 1994. Mengenal Satwa Langka Sulwesi Burung Maleo (Mancrocephalon Maleo). Rimba Sulawesi I ( I ) : 12-21.

Gunawan, H. 1995. Pembinaan Habitat Burung Maleo (Mancrocephalon Maleo SAL, MULLER 1846 ), Balai Penelitian Kehu-tanan. Ujung Pandang. Informasi Tekhnis No. 4:1-15.

Kinnaird, M. F., 1997. Sulawesi Utara: Sebuah Panduan Sejarah Alam, Yayasan Pengembangan Wallacea. GEF- Biodiversity Collection Project Sulut.

Lee, R. J., J. Riley dan R. Merrill. 2001. Keanekaragaman Hayati dan
Konservasi di Sulawesi Bagian Utara, WCS - IP dan NRM.

Mac Kinnon, J. 1987. Metods For Conservation Of Maleobirds, Macrocephalon Maleo, On The Island Of Sulawesi, Indonesia. Biology Coneservation, $20: 183.193$.

Manik, H. 2008. Ekologi Persarangan Burung Maleo Gunung (Aepypodius arfakianus) Pada Areal Aliran Kali Mokwam Kabu-paten Manokwari Papua Barat. Jurnal Ilmu Peternakan, 6:34-43. Desember 2008.

Paputungan, U. 2006. Kajian morfometrik jenis kelelawar (Microchiroptera) di kawasan Taman Nasional Nani Wartabone Kabupa-ten Bolaang Mongondow Provinsi Sulawesi Utara. Jurnal Zootek, Vol. 22:29-35.

Paputungan, U. 2007. Densitas, dominansi dan biodiversitas satwa di perbatasan cagar alam Gunung Ambang dan Perkebunan Ko-pi desa Liberia kecamatan Modayag Kabu-paten Bolaang Mongondow Provinsi Sulawesi Utara. Jurnal Zootek, Vol. 24:35-44.

Sulu, M. P. 1991. Burung Maleo Fauna Endemik Sulawesi Yang Nyaris Punah. Spektrum XV (148) : $22-23$.

Summers, M. 2007. Report of conservation activities at Maleo nesting ground Libuun, Taima, Tompotika, Central Sulawesi, Indonesia August 2006 June 2007. Megapode Newsletter 20(1): 4-5.

Tarmuji. 1978. Mengenal Burung Maleo, Sub Balai Perlindungan dan Pelestarian Alam Sulawesi Utara, Manado. Informasi Tekhnis No. 1:21-32. 
Jurnal Zootek (“Zootek” Journal ) Vol. 36 No. 2 : 289 - 301 (Juli 2016) ISSN 0852 -2626

Tasirin, J. 2007. The release of 4000th maleo chick in Sulawesi. Megapode Newsletter 20(1): 7-8. van As, J. 2007. Maleo nesting ground project in Tangkoko, North-Sulawesi, Indonesia. Megapode Newsletter 20(1): 6-7. 